SJîñn Jurnal

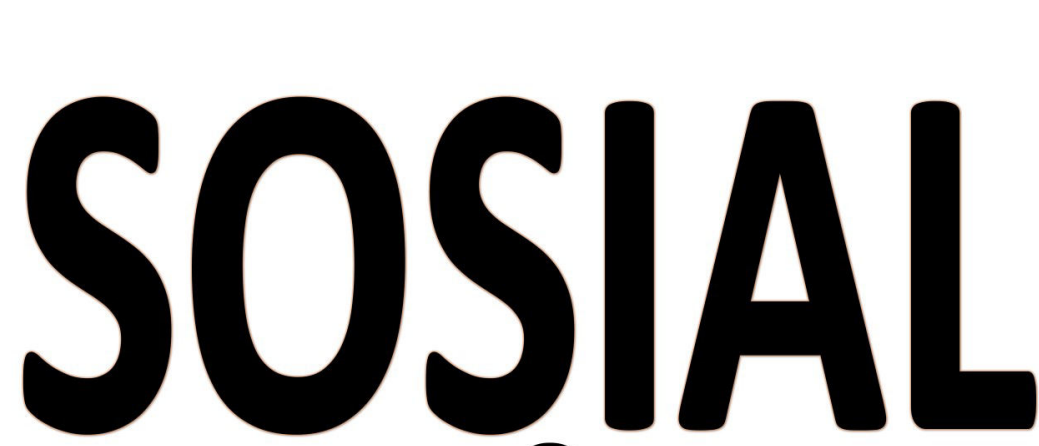

P-ISSN: 2356-1459 E-ISSN: 2654-9050 Vol. 7 No. 7 (2020)
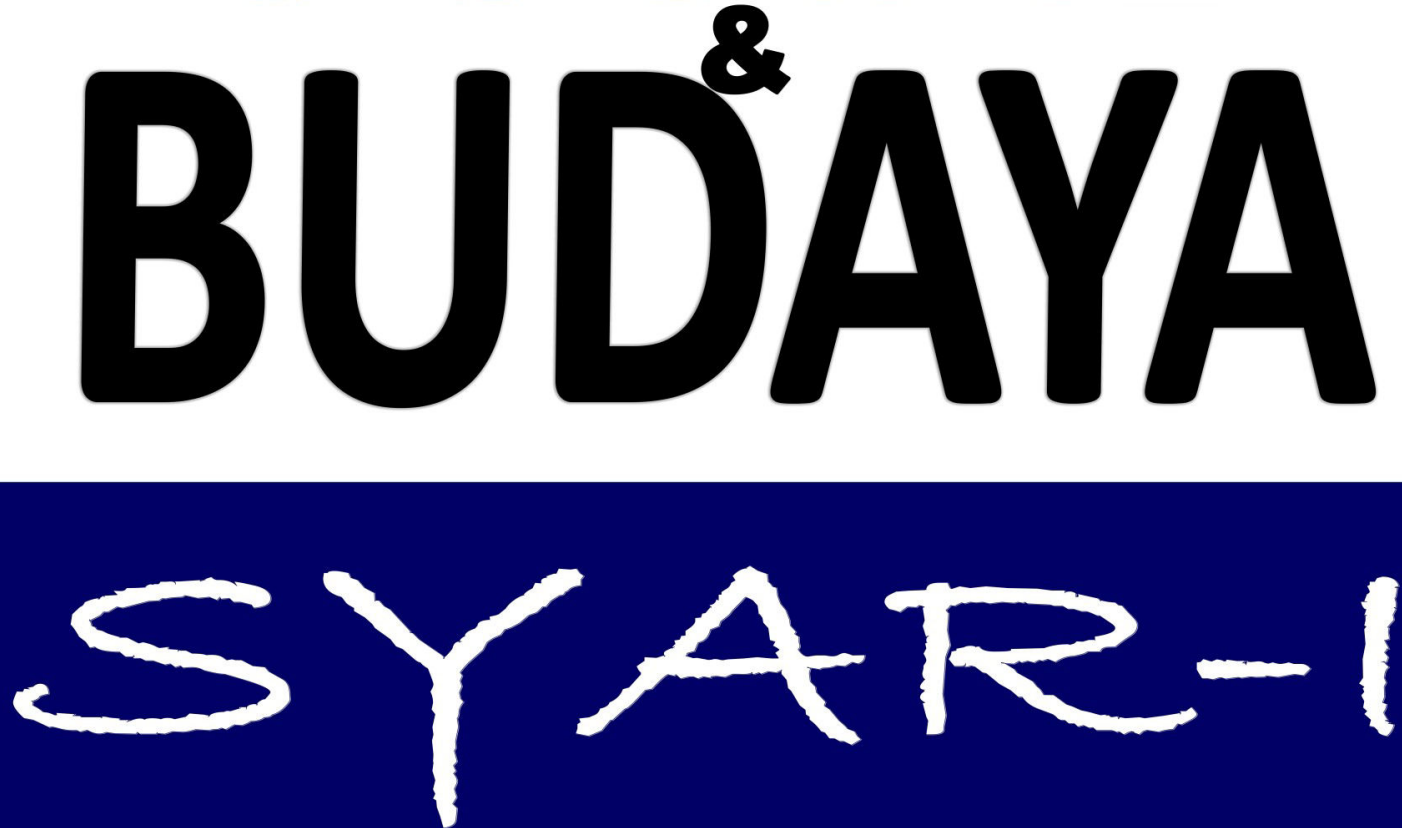

Optimasi Peran Negara Menghadapi Pandemi Corona Virus Disease 2019 dalam Perspektif Hukum Tata Negara Darurat

Rezky Panji Perdana Martua Hasibuan \& Anisa Ashari

Kedudukan Peraturan Pemerintah Pengganti Undang-Undang Nomor 1 Tahun 2020 Terkait Covid-19 Perspektif Ilmu Perundang-Undangan

Tigor Einstein, Muhammad Ishar Helmi \& Ahmad Ramzy

Konstitusionalitas Pemerintah Daerah dalam Menetapkan Kebijakan Lockdown pada Penanganan Covid-19 Raines Wadi

Peran Ekonomi dan Keuangan Sosial Islam Saat Pandemi Covid-19

Azwar Iskandar, Bayu Taufiq Possumah \& Khaerul Aqbar

Pembatasan Sosial Berskala Besar (PSBB) dan Masyarakat Berpenghasilan Rendah

Rindam Nasruddin \& Islamul Haq

Psikoterapi Spiritual dan Pendidikan Islam dalam mengatasi dan menghadapi gangguan Anciety Disorder di saat dan pasca Covid-19

Yono, Indriya Rusmana \& Hielda Noviyanty

Covid-19: Tinjauan Maqasid Al-Shariah Terhadap Penangguhan Pelaksanaan Ibadah Shalat Di Tempat Ibadah (Hifdz al-Nafs Lebih Utama Dari Hifdz al-Din?)

Hudzaifah Achmad Qotadah 


\title{
Peran Ekonomi dan Keuangan Sosial Islam Saat Pandemi Covid-19*
}

\author{
Azwar Iskandar ${ }^{1}$, Bayu Taufiq Possumah ${ }^{2}$, Khaerul Aqbar ${ }^{3}$ \\ Sekolah Tinggi Ilmu Islam dan Bahasa Arab (STIBA), Makassar \\ Intstitut Tazkia, Bogor \\ d. \\ $10.15408 /$ sjsbs.v7i7.15544
}

\begin{abstract}
This research was conducted with the aim of elaborating some Islamic economic and financial policy solutions and roles that could be offered to face of the Covid-19 pandemic in Indonesia. This research used descriptive qualitative approach with content analysis techniques and library research. The results of the research show that among the solutions that can be offered within the framework of the concept and system of Islamic Social, Economics, and Finance are: (1) by distributing direct cash assitence from zakat, infaq, and alms; (2) by strengthening waqf in the form of money waqf, productive waqf, sukuk linked waqf or waqf for infrastructure; (3) through capital assistance of leading venture for the business sector or micro, small, and medium enterprises (UMKM); (4) through the scheme of qardhul hasan; (5) improvement of Islamic economic and financial literacy; (6) through the development of Islamic financial technology.
\end{abstract}

Keywords: economy, finance, social, Islam, Covid-19

\begin{abstract}
Abstrak
Penelitian ini dilakukan dengan tujuan untuk memaparkan beberapa solusi dan peran kebijakan ekonomi dan keuangan sosial Islam yang dapat ditawarkan dalam menghadapi pandemi Covid-19 di Indonesia. Penelitian ini menggunakan metode pendekatan kualitatif deskriptif dengan teknik content analysis (analisis isi) dan riset kepustakaan (library research). Hasil penelitian menunjukkan bahwa di antara solusi yang dapat ditawarkan dalam kerangka konsep dan sistem Ekonomi dan Keuangan Sosial Islam adalah: (1) dengan penyaluran bantuan langsung tunai yang berasal dari zakat, infak dan sedekah; (2) dengan penguatan wakaf baik berupa wakaf uang, wakaf produktif, waqf linked sukuk maupun wakaf untuk infrastruktur; (3) melalui bantuan modal usaha unggulan untuk sektor usaha atau Usaha Mikro Kecil Menengah (UMKM); (4) melalui skema qardhul hasan; (5) peningkatan literasi ekonomi dan keuangan syariah; (6) melalui pengembangan teknologi finansial syariah.
\end{abstract}

Kata Kunci: Ekonomi, Keuangan, Sosial, Islam, Covid-19

${ }^{*}$ Diterima: 14 April 2020, Revisi: 22 Mei 2020, Diterbitkan 12 Juni 2020.

1 Azwar Iskandar adalah Staf pada Pusat Penelitian dan Pengabdian Masyararakat (P3M), Sekolah Tinggi Ilmu Islam dan Bahasa Arab (STIBA) Makassar. Email: azwar@stiba.ac.id.

${ }^{2}$ Bayu Taufiq Possumah adalah Dosen sekaligus Direktur Pascasarjana, Institut Tazkia Bogor. Email: btaufiq@gmail.com

${ }^{3}$ Khaerul Aqbar adalah Dosen sekaligus Kepala Pusat Penelitian dan Pengabdian Masyararakat (P3M), Sekolah Tinggi Ilmu Islam dan Bahasa Arab (STIBA) Makassar. Email: khaerul@stiba.ac.id. 


\section{Pendahuluan}

Wuhan, sebuah kota di Republik Rakyat Tiongkok, mendadak terkenal di seantero dunia. Di kota berpenduduk sekitar 9 juta jiwa itu, serangan virus Corona (Covid-19) bermula. Tak hanya di daratan Tiongkok saja, virus ini juga telah menyebar ke lebih dari 180 negara/kawasan di dunia hingga Maret 2020. Organisasi Kesehatan Dunia (WHO) akhirnya mengumumkan status pandemi global pada 11 Maret 2020. Berdasarkan data yang ada, dampak Covid-19 pada ekonomi Tiongkok berakibat perlambatan pertumbuhan ekonomi dari 6,1\% tahun lalu menjadi hanya sekitar 3,8\% tahun ini, dengan catatan pandemi tidak bertambah buruk. Jika keadaan memburuk pertumbuhan bisa hanya $0,1 \%$ atau bahkan minus.

Sebagai negara dengan ekonomi terbesar kedua di dunia, merosotnya ekonomi Tiongkok tentu saja berdampak terhadap perekonomian global. Dampak negatif pandemi ini dengan cepat menyebar ke seluruh dunia, tidak hanya karena sifatnya virus yang menular, tetapi juga karena mobilitas penduduk dunia dan global value chains yang memang memiliki tingkat konektifitas yang sangat tinggi. Beberapa lembaga riset kredibel dunia memprediksi dampak buruk penyebaran wabah ini terhadap ekonomi global. JP Morgan memprediksi ekonomi dunia minus 1,1\% di 2020, EIU memprediksi minus 2,2\%, Fitch memprediksi minus 1,9\%, dan IMF memprediksi ekonomi dunia minus 3\% di 2020. ${ }^{4}$ Untuk Indonesia sendiri, Menteri Keuangan Republik Indonesia, Sri Mulyani Indrawati, memprediksi pertumbuhan ekonomi dalam skenario terburuk mencapai minus $0,4 \% .^{5}$

Menurut Bank Dunia ${ }^{6}$, dampak ekonomi dari Covid-19 ini akan menghentikan usaha hampir 24 juta orang di Asia Timur dan Pasifik. Di bawah skenario terburuknya, Bank Dunia juga memperkirakan hampir 35 juta orang akan tetap dalam kemiskinan. Bahkan, melalui sejumlah skenario dengan mempertimbangkan berbagai garis kemiskinan, Bank Dunia memperkirakan jumlah orang yang hidup dalam kemiskinan ekstrim akan meningkat hingga 922 juta di seluruh dunia. Sebuah angka yang fantastis.

Di antara bentuk upaya yang diserukan dan dilakukan oleh dunia dalam rangka mengurangi penyebaran wabah ini adalah dengan social atau physical distancing. Namun sayangnya, gerakan ini membawa pengaruh pada penurunan aktivitas ekonomi secara keseluruhan.

${ }^{4}$ Richard Baldwin and Beatrice Weder di Mauro, "Economics in the Time of Covid-19", New E-Book. The Graduate Institute Geneva (April 2020): p. 1-10.

${ }^{5}$ Azwar. Solusi Ekonomi dan Keuangan Islam di Masa Pandemi Covid-19.

https://www.kemenkeu.go.id/publikasi/artikel-dan-opini/solusi-ekonomi-dan-keuangan-islam-sa at-pandemi-covid-19/

Diakses pada tanggal 4 Mei 2020.

"World Bank, "World Bank Group and COVID-19 (coronavirus)".

https://www.worldbank.org/en/who-we-are/news/coronavirus-covid19. Diakses pada tanggal 4 Mei 2020. 


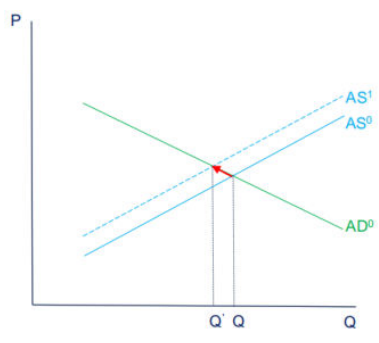

(1)

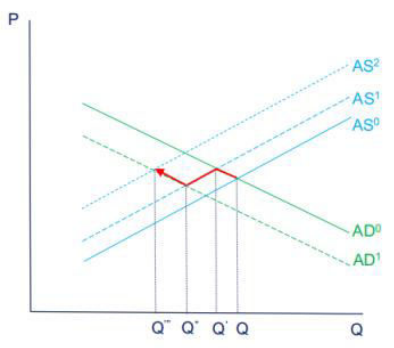

(3)

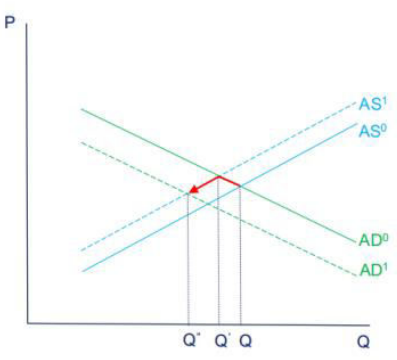

$(2)$

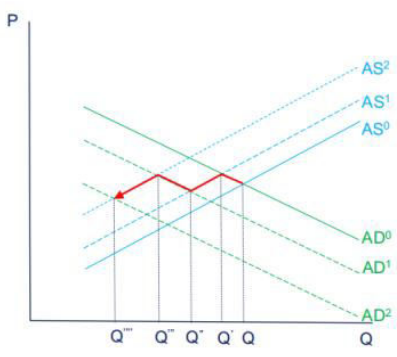

$(4)$

Gambar 1. Kurva Pergeseran Supply dan Demand Akibat Covid-19 Sumber: Surico dan Galeotti ${ }^{7}$

Menurut Surico dan Galeotti ${ }^{8}$ (lihat Gambar 1), di awal kemunculannya, dengan adanya physical distancing ataupun pengetatan dan pembatasan aktivitas masyarakat lainnya, pendemi ini memberikan shock terhadap sisi penawaran (supply) dalam perekonomian, sehingga Aggregate Supply (AS) bergeser dari AS ke AS yang berakibat terjadi penurunan produksi dari $Q$ ke $Q^{\prime}$. Kemudian dengan suasana diam di rumah tersebut, konsumen hanya akan melakukan pembelian barang yang pokok dengan catatan bisa dilakukan segera sehingga berdampak pada sisi permintaan (demand), dimana Aggregate Demand ( $\mathrm{AD}$ ) bergeser dari $\mathrm{AD}^{0}$ ke $\mathrm{AD}^{1}$ dan produksi turun dari $\mathrm{Q}^{\prime}$ ke Q" disebabkan karena adanya ketidakpastian terhadap keberlangsungan wabah, kebijakan ekonomi yang akan diambil untuk mengurangi dampak wabah, sebagian besar pekerja akan kehilangan pendapatan khususnya pada sektor industri, dan lainnya. Perusahaan-perusahaan atau pelaku usaha, khususnya yang sangat bergantung dengan arus kas (cash flow) mengalami keterbatasan likuiditas untuk memenuhi kewajibannya kepada pihak ketiga. Berdasarkan hukum supply dan demand, penurunan permintaan akibat program tetap di rumah (stay at home) pada gilirannya akan memicu penurunan jumlah produksi dengan bergesernya $\mathrm{AS}^{1}$ ke $\mathrm{AS}^{2}$ dan dari $\mathrm{Q}^{\prime \prime}$ menjadi $Q^{\prime \prime \prime}$. Dan seterusnya terjadi reaksi penurunan permintaan sehingga kurva AD1 bergeser ke AD2 dan produksi berkurang kembali ke $\mathrm{Q}^{\prime \prime \prime}$.

7 Paolo Surico and Andrea Galeotti, "The economics of a pandemic: The Case of Covid-19", Working Paper. London Business School (2020): p. 69-73.

8 Idem. 


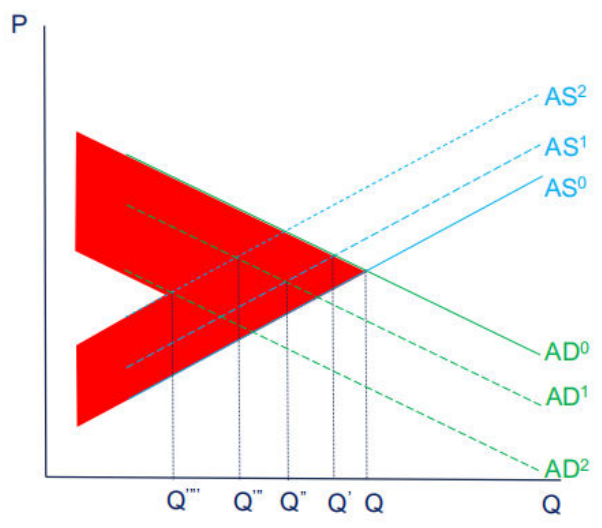

Gambar 2. Kurva Kondisi Stagnan Ekonomi Akibat Covid-19

\section{Sumber: Surico dan Galeotti ${ }^{9}$}

Selanjutnya, proses penurunan perekonomian yang berantai ini menunjukkan bahwa bencana yang ditimbulkan virus Covid-19 ini terhadap perekonomian bukan hanya menimbulkan guncangan penurunan (besar) pada fundamental ekonomi riil, namun juga merusak kelancaran mekanisme pasar dan membentuk semacam 'tembok penghalang' antara permintaan dan penawaran. Lebih lanjut, hal tersebut menimbulkan reaksi berantai menuju penurunan pada ekonomi riil. Adanya kontraksi dalam pasokan, yang mengarah kepada kontraksi dalam permintaan, pada akhirnya melenyapkan surplus ekonomi (area berbayang merah di bagan di sebelah bawah) (lihat Gambar 2) ${ }^{10}$.

Mengingat bahwa aspek-aspek vital ekonomi yaitu supply, demand dan supply-chain telah terganggu, maka dampak krisis akan dirasakan secara merata ke seluruh lapisan atau tingkatan masyarakat. Berhubung karena ketahanan setiap lapisan atau tingkatan tersebut berbeda-beda, maka masyarakat ekonomi golongan menengah ke bawah khususnya mikro dan informal dengan pendapatan harian, tentu menjadi kelompok yang paling rentan terkena dampaknya. Dampak di sektor riil tersebut kemudian akan menjalar ke sektor keuangan yang tertekan (distress) karena sejumlah besar investee akan mengalami kesulitan pembayaran kepada investornya.

Dengan kondisi di atas, timbul pertanyaan besar: bagaimana Indonesia mampu melaluinya? Apa yang dimiliki bangsa ini agar mampu bertahan di tengah gelombang wabah yang belum pasti kapan akan berakhir? Secercah harapan besar sejatinya ada dalam diri bangsa Indonesia. Sebagai negara dengan populasi muslim terbesar di dunia, umat Islam dapat memberikan peran terbaiknya melalui berbagai bentuk atau model philanthropy ${ }^{11}$ dalam Ekonomi dan Keuangan Syariah. Islam sebagai agama

9 Idem.

${ }^{10}$ Institut Tazkia, “Tujuh Paket Ekonomi dan Keuangan Syariah Mengatasi Dampak Krisis Covid-19", (April 2020): h. 1-7.

11 Istilah philanthropy berasal dari bahasa Yunani, yaitu philos (cinta) dan anthropos (manusia). Secara harfiah, philanthropy adalah konseptualisasi dari praktik memberi (giving), pelayanan (services) dan asosiasi (association) secara sukarela untuk membantu pihak lain yang membutuhkan sebagai ekspresi rasa cinta. Secara umum filantropi didefenisikan sebagai tindakan sukarela untuk kepentingan public (voluntary action for the public goods), ada dua model model filantropi yang dikenal, 
yang mengajarkan manusia untuk saling menyayangi, mengasihi dan menyantuni, memiliki konfigurasi kedermawanan atau filantropi dari ajarannya. ${ }^{12}$ Di antaranya berupa perintah untuk berinfaq, bershadaqah, berzakat, dan berwakaf, yang dapat berimplikasi selain terhadap peningkatan iman kepada Allah, menumbuhkan rasa kemanusiaan yang tinggi, menghilangkan sifat kikir, rakus dan materialistis, menumbuhkan ketenangan hidup, membersihkan dan mengembangkan harta yang dimiliki, juga dapat mengatasi berbagai masalah dalam kehidupan sosial, ekonomi, pendidikan, lingkungan ${ }^{13}$ dan aspek kehidupan lainnya. Peran ini diharapkan dapat mengatasi guncangan ekonomi yang terjadi dan seluruh masyarakat, khususnya umat muslim, dapat ikut serta berkontribusi dalam memulihkan guncangan tersebut.

Berangkat dari hal tersebut, penelitian ini dilakukan dengan tujuan untuk memaparkan beberapa solusi dan peran kebijakan ekonomi dan keuangan sosial Islam yang dapat ditawarkan dalam menghadapi pandemi Covid-19 di Indonesia.

\section{METODE PENELITIAN}

Penelitian ini menggunakan metode pendekatan kualitatif deskriptif merupakan upaya memahami berbagai konsep yang ditemukan dalam proses penelitian, dengan menggunakan teknik content analysis (analisis isi) dan riset kepustakaan (library research). Teknik content analysis merupakan metode penelitian yang digunakan untuk mengetahui simpulan dari sebuah teks. Atau dengan kata lain, analisis isi merupakan metode penelitian yang ingin mengungkap gagasan penulis yang termanifestasi maupun yang laten. Sedangkan riset kepustakaan (library research) pada penelitian ini menggunakan jenis dan sumber data sekunder yang diperoleh dari hasil penelitian, artikel dan buku-buku referensi yang membahas topik yang berkaitan dengan tema penelitian. ${ }^{14}$

yaitu filantropi tradisional yang berbasis pada karitas dan kedua filantropi untuk keadilan social (social justice philanthropy). (Lihat: Sakni, A. S. (2013). Konsep Ekonomi Islam dalam Mengentaskan Kesenjangan Sosial: Studi atas Wacana Filantropi Islam dalam Syari'at Wakaf. Jurnal Ilmu Agama: Mengkaji Doktrin, Pemikiran, dan Fenomena Agama, 14(1), 151-166).

12 Uyun, Q., Zakat, Infaq, Shadaqah, dan Wakaf Sebagai Konfigurasi Filantropi Islam, (Islamuna: Jurnal Studi Islam, vol. 2, No. 2, 2015), h. 218-234.

${ }^{13}$ Kasdi, A., Filantropi Islam Untuk Pemberdayaan Ekonomi Umat (Model Pemberdayaan ZISWAF di BMT Se-Kabupaten Demak) (Iqtishadia: Jurnal Kajian Ekonomi dan Bisnis Islam STAIN Kudus, Vol. 9, No. 2, 2016), h. 227-245.

${ }^{14}$ Azwar Iskandar dan Khaerul Aqbar, "Kedudukan Ilmu Ekonomi Islam di Antara Ilmu Ekonomi dan Fikih Muamalah: Analisis Problematika Epistemologis", Nukhbatul 'Ulum: Jurnal Bidang Kajian Islam, Vol. 5, No. 2 (2019), h. 88-105. 


\section{PEMBAHASAN}

\section{Solusi Ekonomi dan Keuangan Sosial Islam}

Di antara solusi yang dapat ditawarkan dalam kerangka konsep dan sistem Ekonomi dan Keuangan Sosial Islam adalah:

Pertama, penyaluran bantuan langsung tunai yang berasal dari zakat, infak dan sedekah, baik yang berasal dari unit-unit pengumpul zakat maupun dari masyarakat. Menghadapi situasi seperti saat ini, bukan hanya pemerintah yang bergerak, masyarakat pun diharapkan dapat berkontribusi sesuai dengan kemampuan dan kondisinya masing-masing. Dalam konteks ini, diperlukan pengorbanan dari orang kaya dan kesabaran dari orang miskin yang terdampak wabah, atas dasar cinta yang diwujudkan dalam bentuk solidaritas sesama manusia, di mana orang yang lebih beruntung membantu mereka yang kurang beruntung ${ }^{15}$. Salah satu bentuk nya, di tengah pandemi Covid-19, adalah dengan menunaikan zakat, infak, dan sedekah. Khusus untuk zakat yang ditunaikan, penyalurannya dapat difokuskan kepada orang miskin yang terdampak Covid-19 secara langsung, sebagai salah satu yang berhak menerimanya (mustahik).

Hal ini adalah skema philanthropy Ekonomi Islam yang memiliki potensi besar bagi perekonomian masyarakat. Namun sayangnya, realisasi zakat yang masuk ke Baznas masih jauh dari harapan. Realisasi zakat di akhir tahun 2018 tercatat hanya Rp 8,1 triliun, padahal potensinya mencapai Rp 252 triliun. Untuk itu, penguatan kampanye dana zakat, infak, dan sedekah dapat terus digiatkan. Diantara upaya yang dapat dilakukan adalah:

1. Menjadikan masjid sebagai pusat baitul maal untuk masyarakat sekitarnya dan wajib didaftar sebagai Unit Pengumpul Zakat (UPZ) di bawah koordinasi Organisasi Pengelola Zakat (OPZ). Meski masjid-masjid saat ini sementara tidak difungsikan, di era media sosial ini jamaah masjid tetap dapat digerakkan dengan membayar zakat secara online;

2. Literasi terkait perhitungan zakat dapat dikuatkan dengan pendirian Zakat Centre di masjid dan kampus-kampus;

3. Perlu menyerukan gerakan Solidarity Fund secara nasional dan besar-besaran yang dapat dipimpin langsung oleh Presiden Republik Indonesia yang didukung oleh seluruh media mainstream nasional atau media sosial resmi pemerintah dan masyarakat. Jika zakat melibatkan dua pihak, yaitu pemerintah atau yang mewakilinya, dalam hal ini amil zakat (Baznas), dan wajib zakat (muzakki), maka infak dan sedekah sifatnya lebih fleksibel, karena hanya berasal dari satu pihak saja yaitu pembayar/pemberi infak atau sedekah, sehingga pengumpulan dan penyaluran dapat dilakukan lebih maksimal untuk masyarakat terdampak Covid-19.

15 Linge, A., Filantropi Islam Sebagai Instrumen Keadilan Ekonomi (Jurnal Perspektif Ekonomi Darussalam, Vol . 1, No. 2, 2015), h. 154-171. 
Kedua, penguatan wakaf uang baik dengan skema wakaf tunai, wakaf produktif maupun waqf linked sukuk perlu ditingkatkan. Badan Wakaf Indonesia (BWI) perlu bekerja sama dengan lembaga keuangan syariah untuk mempromosikan skema wakaf ini, yang pada akhirnya dapat digunakan untuk pembangunan berbagai infrastruktur berbasis wakaf seperti Rumah Sakit Wakaf (RSW) khusus korban Covid-19, Alat Pelindung Diri (APD) wakaf, masker wakaf, poliklinik wakaf, Rumah Isolasi Wakaf (RIW), pengadaan ventilator wakaf, universitas wakaf dan lainnya. Manajemen wakaf harus dilakukan secara profesional, sehingga wakaf dapat dimanfaatkan secara produktif dan berkelanjutan, mengingat realita bahwa banyak harta benda wakaf yang ada, tetapi kurang dan bahkan tidak diproduktifkan, sehingga tidak bermanfaat secara maksimal. ${ }^{16}$ Bahkan, dengan perkembangan saat ini, wakaf dapat saja berbentuk benda apa saja yang bernilai ekonomi, antara lain paten sebagai wakaf produktif. Jika saatnya nanti vaksin untuk Covid-19 ditemukan, diharapkan patennya dapat diwakafkan, sehingga dapat digunakan untuk seluruh masyarakat dunia. Oleh karena itu, penting untuk mengampanyekan pentingnya wakaf saat wabah pandemi Covid-19 kepada masyarakat termasuk kepada ilmuwan dan penemu (peneliti vaksin).

Seperti yang diketahui, wakaf memiliki peran yang sangat besar dalam pembangunan infrastruktur pada berbagai macam fasilitas umum dan pemberdayaan ekonomi umat ${ }^{17}$, dimana wakaf tunai adalah satu alternatif yang diharapkan dapat mengatasi permasalahan kemiskinan di tengah masyarakat (khususnya bagi mereka yang terdampak Covid-19), dengan adanya partisipasi aktif dari pihak non pemerintah (masyarakat), khususnya golongan kaya dan memiliki kemampuan untuk membantu meringankan penderitaan masyarakat miskin. Salah contoh di Bangladesh, upaya non pemerintah untuk menjawab masalah kemiskinan telah dicoba dijawab melalui keberadaan lembaga yang bernama Social Investment Bank Limited (SIBL). ${ }^{18}$ Lembaga ini beroperasi dengan menggalang dana masyarakat (kaya), khususnya melalui dana wakaf tunai, untuk kemudian dikelola dan hasil pengelolaannya disalurkan untuk masyarakat miskin. Pada kasus di Indonesia, upaya seperti yang dilakukan oleh SIBL tersebut, merupakan satu alternatif yang menarik dan patut untuk diakomodir. Dengan jumlah penduduk muslim yang mayoritas, upaya penggalangan dan pengelolaan dana wakaf (tunai) seperti halnya di Bangladesh, diharapkan dapat lebih ter apresiasikan oleh masyarakat (muslim), minimal secara kultural, khususnya di masa-masa pendemi seperti ini.

Ketiga, bantuan modal usaha unggulan saat krisis. Di tengah-tengah krisis, tidak sedikit sektor usaha atau Usaha Mikro Kecil Menengah (UMKM) yang berjuang agar tetap eksis. Usaha ini seringkali sulit bertahan karena keterbatasan permodalan. Keberadaan UMKM sebagai kelompok non-muzakki adalah kelompok yang sangat

16 Sakni, A. S., Konsep Ekonomi Islam dalam Mengentaskan Kesenjangan Sosial: Studi atas Wacana Filantropi Islam dalam Syari'at Wakaf (Jurnal Ilmu Agama: Mengkaji Doktrin, Pemikiran, Dan Fenomena Agama, Vol. 14, No. 1, 2013), h. 151-166.

17 Asri, A., Aqbar, K., \& Iskandar, A., Hukum dan Urgensi Wakaf Tunai dalam Tinjauan Fikih (BUSTANUL FUQAHA: Jurnal Bidang Hukum Islam, Vol. 1, No. 1, 2020), h. 79-92.

${ }_{18}$ https://www.siblbd.com/retail/deposit details/Cash-Waqf-Deposit 
rentan untuk jatuh ke dalam jurang kemiskinan dan kebangkrutan karena guncangan atau hantaman shock ekonomi. Sehingga jumlah mustahik dapat meningkat dengan sangat tajam, sementara jumlah muzakki dapat terus menurn secara signifikan. ${ }^{19}$

Keberadaan pengusaha mikro kecil dan menengah, khususnya pedagang di pasar tradisional merupakan wujud kehidupan ekonomi sebagian besar rakyat Indonesia. Posisi ini telah menempatkan pedagang pasar tradisional sebagai hal utama yang harus mendapat perhatian, terutama dalam hal permodalan. Proses pengembangan pedagang pasar tradisional adalah manifestasi dari perkembangan ekonomi yang menjadi sangat penting. Upaya pengembangan dan penguatan potensi pedagang pasar tradisional sebagai kelompok ekonomi strategis harus berorientasi pada pemberdayaan, sehingga terbentuk pelaku ekonomi lokal yang mandiri dan kuat melalui Lembaga Keuangan Mikro (LKM) khususnya Lembaga Keuangan Mikro Syariah (LKMS). ${ }^{20}$ Oleh karena itu, pemberian modal pada usaha dijadikan sebagai sarana mengurangi dampak krisis. Pemberian modal ini dapat dilakukan dengan beberapa alternatif kebijakan, seperti pemberian stimulasi tambahan relaksasi perbankan syariah dan restrukturisasi atau penangguhan pembayaran kredit/pembiayaan syariah selama beberapa bulan ke depan. Agar lebih kuat, pemberian permodalan dari perbankan/lembaga keuangan syariah ini perlu didukung dan dikuatkan dengan pendampingan sehingga dapat dipertanggungjawabkan.

Keempat, permodalan usaha di atas juga dapat diikuti dengan dengan pinjaman qardhul hasan. Dalam terminologi ekonomi/keuangan syariah, qardhul hasan adalah pinjaman yang tidak mengambil manfaat (keuntungan) apa pun namun tetap ditekankan untuk dibayarkan kembali. ${ }^{21}$ Produk/skema ini merupakan salah satu produk/skema sistem keuangan syariah yang sangat penting dalam mendukung pemulihan atau menopang perekonomian. Diantara pilihan penyaluran yang dapat dilakukan adalah melalui:

1. Lembaga Keuangan Mikro Syariah (LKMS) dalam membiayai usaha nano dimana dananya dapat berasal dari beberapa sumber, baik dari masyarakat umum, perusahaan swasta maupun BUMN/BUMD;

2. Pinjaman langsung tanpa margin baik untuk usaha maupun konsumsi yang disalurkan oleh perusahaan (swasta atau BUMN/BUMD) kepada karyawan atau mitranya (seperti pengemudi ojek online) dimana dananya dapat berasal dari dana Corporate Social Responsibility (CSR) atau pos lainnya. Untuk meningkatkan dana CSR, pemerintah perlu mempertegas kewajiban dan kontribusi CSR yang lebih tinggi baik dari BUMN/BUMD maupun perusahaan swasta. Dalam pandangan Islam, aktivitas bisnis adalah bagian dari kewajiban keagamaan. Social reponsibility (pertanggungjawaban sosial) mengacu

19 Ascarya, The Role of Islamic Social Finance in Times of Covid-19 Outbreak, PEBS-UI (April 2020):h. 25.

${ }_{20}$ Sabirin, S., \& Sukimin, D. A., Islamic Micro Finance Melati: Sebuah Upaya Penguatan Permodalan bagi Pedagang Pasar Tradisional (Economica: Jurnal Ekonomi Islam, Vo. 8, No. 1, 2017), h. 27-53.

21 Sari, S. P., Pengaruh Pembiayaan Qardhul Hasan Terhadap Peningkatan Pendapatan Usaha Mustahik Zakat (Studi Kasus Dompet Peduli Umat Daarut Tauhiid Cabang Bogor) (AL-INFAQ, Vol. 4, No. 1, 2015), 57-93. 
pada kewajiban-kewajiban di mana organisasi harus melindungi dan berkontribusi pada masyarakat dimana organisasi itu berada. Di dalam Islam dikenal konsep persaudaraan dan keadilan sosial, yang bisa dilakukan dengan cara berbagi keuntungan/kemakmuran dengan masyarakat di sekitarnya. Dengan cara seperti itu, perusahaan tersebut telah menunaikan tanggung jawab sosial perusahaannya. ${ }^{22}$

3. Baitul Mal wa Tamwil (BMT), melalui Baitul Mal-nya menjadi salah satu lembaga yang dapat berperan serta dalam memberikan solusi terhadap masalah ini, yaitu dengan cara melaksanakan program-program pemberdayaan melalui produk qardhul hasan. ${ }^{23}$ Implementasi qardhul hasan ini tidak hanya berfungsi sebagai wadah pembiayaan semata, akan tetapi bentuk pembiayaan ini juga dibekali dengan model pendampingan, sehingga dengan adanya pendampingan ini pelaksanaan model pembiayaan dapat berjalan dengan baik dan pada akhirnya tujuan mulia ini juga akan terwujud.

Kelima, selain dari sektor perbankan syariah dan qardhul hasan, sebagian dana yang dikumpulkan oleh unit-unit atau organisasi pengumpul zakat, khususnya yang ada di daerah, dapat digunakan untuk memperkuat usaha UMKM. Menyelamatkan kelompok UMKM yang krisis atau terancam bangkrut karena terkena dampak ekonomi dari wabah Covid-19, dapat dikategorikan sebagai golongan asnaf (penerima zakat), yaitu sebagai kelompok miskin, berjuang di jalan Allah (fii sabilillah), atau orang yang berhutang (gharimin).

Keenam, Sistem Ekonomi dan Keuangan Syariah sebagai sistem yang sarat dengan nilai sekaligus merupakan petunjuk dari Sang Pencipta diyakini mampu mewujudkan kegiatan ekonomi yang produktif dalam kerangka keadilan. Untuk itu, masyarakat perlu diberi pemahaman yang benar tentang ekonomi dan keuangan syariah dalam rangka peningkatan literasi ekonomi dan keuangan syariah, diantaranya melalui pengadaan bantuan pendidikan ekonomi syariah untuk mahasiswa terkena dampak Covid-19; pemberian perizinan dan fasilitas bagi Perguruan Tinggi Negeri dan Swasta untuk menjalankan program Program Jarak Jauh (PJJ) yang menawarkan program Ekonomi Syariah dengan salah satu penekanan pada pembinaan akhlak; dan perluasan infrastruktur sambungan internet penunjang PJJ yang merata di seluruh Indonesia secara gratis.

Selain itu, keberadaan Organisasi Masyarakat Ekonomi Syariah sebagai wadah yang bertujuan menjadi acuan dan diikuti sebagai teladan bagi usaha percepatan pengembangan dan penerapan sistem ekonomi serta etika bisnis islami di Indonesia dapat dilibatkan dalam upaya ini $^{24}$. Literasi Keuangan Syariah di Indonesia masih

22 Satrio, M. A., Qardhul Hasan Sebagai Wujud Pelaksanaan CSR dan Kegiatan Filantropi Lembaga Keuangan Syariah Untuk Pemberdayaan Masyarakat (Kajian Bisnis Sekolah Tinggi Ilmu Ekonomi Widya Wiwaha, Vol. 23, No. 2, 2015), h. 104-111.

${ }_{23}$ Mubarok, F. K., Optimalisasi Produk Qardhul Hasan Dalam Memberdayakan Ekonomi Umat (AKUNTABEL, Vol. 16, No. 1, 2019), 62-68.

${ }^{24}$ Lubis, N. I., Peran Masyarakat Ekonomi Syariah (MES) Dalam Meningkatkan Literasi Keuangan Syariah Di Indonesia (Doctoral Dissertation, Universitas Islam Negeri Sumatera Utara, 2019). 
kategori rendah ${ }^{25}$, hanya menempati posisi kesembilan dalam pangsa pasar keuangan syariah di dunia. Dikarenakan tingkat pengetahuan dan ilmu teknologi masyarakat Indonesia juga masih kurang, sehingga banyak masyarakat yang belum mengetahui adanya produk-produk keuangan syariah yang sangat bermanfaat untuk kehidupan.

Ketujuh, pengembangan teknologi finansial syariah untuk memperlancar likuiditas pelaku pasar daring secara syariah, dimana pada saat yang bersamaan juga diupayakan peningkatan fokus pada social finance (zakat, infak, sedekah dan wakaf) di samping commercial finance. Termasuk pula dalam hal ini, pengembangan market place untuk mengumpulkan pasar tradisional dan UMKM yang berjumlah hampir 60 juta saat ini, dengan tujuan mempertemukan permintaan dan penawaran baik di dalam negeri maupun luar negeri, khususnya di masa-masa lockdown karena pandemi. Apalagi penelitian yang ada menyebutkan bahwa permasalahan keuangan, sumberdaya manusia, dan teknologi merupakan permasalahan klasik ${ }^{26}$ yang dihadapi Usaha Mikro, Kecil, dan Menengah (UMKM) di Indonesia. Perkembangan teknologi di bidang keuangan telah berkembang dalam beberapa tahun terakhir ini dan berdampak perubahan perilaku masyarakat dalam bertransaksi keuangan. Hal ini dapat menjadi solusi bagi permasalahan keuangan yang dihadapi UMKM.27

\section{Kondisi Setelah Interfensi ZISWAF}

Ketika seorang mustahik yang menerima zakat memiliki kemampuan untuk membelanjakan harta untuk memenuhi kebutuhannya, maka kondisi akan mengakibatkan bergesernya kurva Demand ke kanan dari $\mathrm{D}^{0}$ ke $\mathrm{D}^{1}$. Di lain pihak, ketika seorang muzakki memiliki aset, ia termotivasi untuk menginvestasikan aset tersebut ke sektor riil sehingga suplai barang dan jasa akan meningkat dan kurva supply akan bergerak ke kanan, dari $\mathrm{S}^{0}$ ke $\mathrm{S}^{1}$.

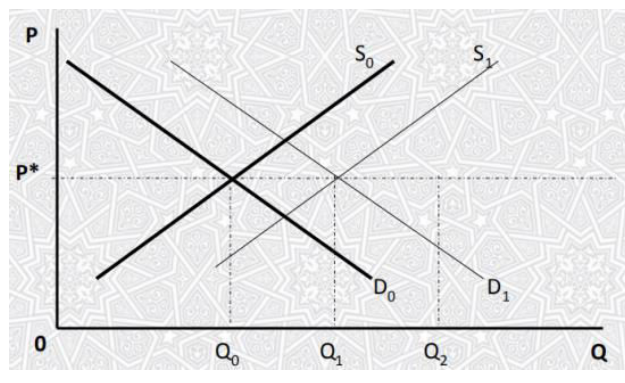

(1)

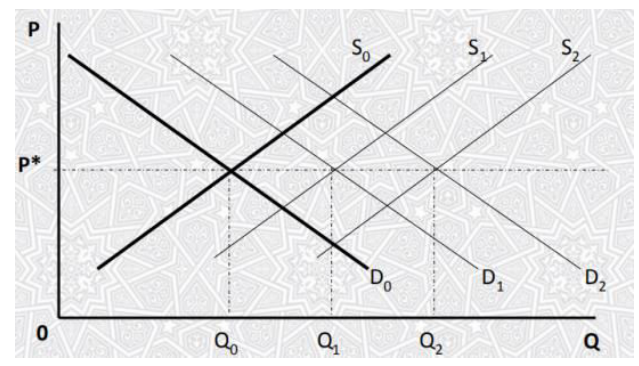

$(2)$

Gambar 3. Intervensi ZISWAF dalam Kurva Demand dan Supply

${ }^{25}$ Hayati, S. R., Strategi Bank Syariah dalam Meningkatkan Literasi Keuangan Syariah pada Masyarakat (Studi Kasus pada BPRS Madina Mandiri Sejahtera) (JESI (Jurnal Ekonomi Syariah Indonesia), Vol. 8, No. 2,2019), h. 129-137.

${ }^{26}$ Hiyanti, H., Nugroho, L., Sukmadilaga, C., \& Fitrijanti, T. Peluang dan Tantangan Fintech (Financial Technology) Syariah di Indonesia (Jurnal Ilmiah Ekonomi Islam, 5(3), 2020), h. 326-333.

27 Yuliana, R. R. R. D. (2019). Sinergi lembaga teknologi finansial dan koperasi dalam pemanfaatan teknologi finansial oleh usaha mikro, kecil, dan menengah di NTB. (Jurnal Ekonomi dan Pembangunan, 27(1), 2019), h. 53-66. 
Kemudian, pada periode pembayaran zakat berikutnya, mustahik tetap memiliki kemampuan untuk membelanjakan harta untuk memenuhi kebutuhannya, sehingga kurva Demand akan terus bergeser ke kanan dari $\mathrm{D}^{1}$ ke $\mathrm{D}^{2}$. Hal ini akan berlangsung terus menerus. Begitu pula, sisi supply juga akan bergerak ke kana, dari $S^{1}$ ke $\mathrm{S}^{2}$, dan terus bergerak. Pada akhirnya, pergerakan sisi demand dan supply ke kanan yang terus menerus lambat laun akan meningkatkan GDP atau GDP per kapita yang berujung pada kesejahteraan dan kemakmuran ${ }^{28}$.
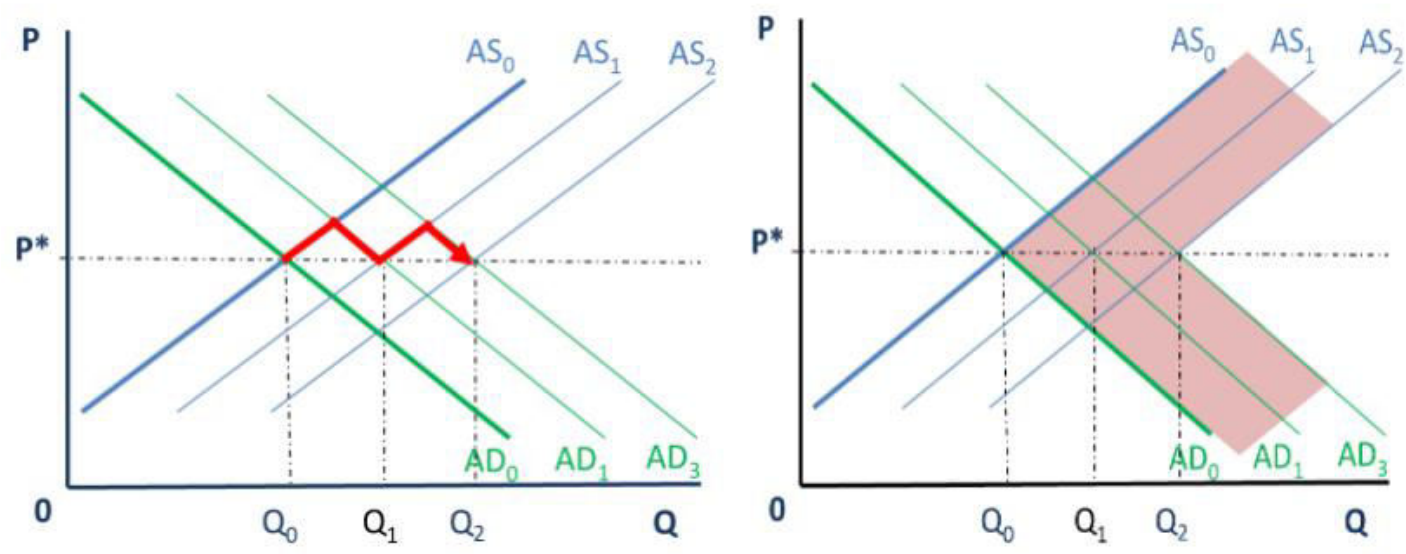

Gambar 3. Kondisi Akhir Perekonomian dengan Intervensi ZISWAF

Pada akhirnya, jika program-program di atas, khususnya bantuan langsung tunai, zakat, infak, wakaf, atau CSR, baik untuk masyarakat maupun sektor usaha atau UMKM, betul-betul dapat digalakkan, maka diharapkan akan meningkatkan kembali aggregate demand dan aggregate supply ke kanan, diikuti dengan pembangunan pasar daring yang fokus kepada UMKM yang mempertemukan permintaan dan penawaran, sehingga surplus ekonomi terbentuk kembali dan membantu percepatan pemulihan ekonomi.

\section{Kesimpulan}

Sebagai negara dengan populasi muslim terbesar di dunia, umat Islam dapat memberikan peran terbaiknya melalui berbagai bentuk atau model philanthropy dalam Ekonomi dan Keuangan Syariah, khususnya dalam masa pandemi Covid-19. Peran ini diharapkan dapat mengatasi guncangan ekonomi yang terjadi dan seluruh masyarakat, khususnya umat muslim, dapat ikut serta berkontribusi dalam memulihkan guncangan tersebut. Di antara solusi yang dapat ditawarkan dalam kerangka konsep dan sistem Ekonomi dan Keuangan Sosial Islam adalah: (1) dengan penyaluran bantuan langsung tunai yang berasal dari zakat, infak dan sedekah; (2) dengan penguatan wakaf baik berupa wakaf uang, wakaf produktif, waqf linked sukuk maupun wakaf untuk infrastruktur; (3) melalui bantuan modal usaha unggulan untuk sektor

28 Ascarya, "The Role of Islamic Social Finance in Times of Covid-19 Outbreak", PEBS-UI (April 2020):h. 29-30. 
usaha atau Usaha Mikro Kecil Menengah (UMKM); (4) melalui skema qardhul hasan; (5) peningkatan literasi ekonomi dan keuangan syariah; (6) melalui pengembangan teknologi finansial syariah. Jika program-program di atas, khususnya bantuan langsung tunai, zakat, infak, wakaf, atau CSR, betul-betul dapat digalakkan, maka diharapkan akan membantu surplus ekonomi terbentuk kembali sehingga percepatan pemulihan ekonomi dapat terwujud.

\section{Referensi:}

Ascarya. (2020). The Role of Islamic Social Finance in Times of Covid-19 Outbreak. PEBS-UI. h. 29-30.

Asri, A., Aqbar, K., \& Iskandar, A. (2020). Hukum dan Urgensi Wakaf Tunai dalam Tinjauan Fikih. BUSTANUL FUQAHA: Jurnal Bidang Hukum Islam, 1(1), 79-92.

Azwar. Solusi Ekonomi dan Keuangan Islam di Masa Pandemi Covid-19. https://www.kemenkeu.go.id/publikasi/artikel-dan-opini/solusi-ekonomi-dan-ke uangan-islam-saat-pandemi-covid-19/. Diakses pada tanggal 4 Mei 2020.

Baldwin, R., Mauro, B.W.D. (2020). Economics in the Time of Covid-19. NEW E-BOOK. The Graduate Institute Geneva. p. 1-10.

Hayati, S. R. (2019). Strategi Bank Syariah dalam Meningkatkan Literasi Keuangan Syariah pada Masyarakat (Studi Kasus pada BPRS Madina Mandiri Sejahtera). JESI (Jurnal Ekonomi Syariah Indonesia), 8(2), 129-137.

Hiyanti, H., Nugroho, L., Sukmadilaga, C., \& Fitrijanti, T. (2020). Peluang dan Tantangan Fintech (Financial Technology) Syariah di Indonesia. Jurnal Ilmiah Ekonomi Islam, 5(3), 326-333.

Institut Tazkia. (2020). Tujuh Paket Ekonomi dan Keuangan Syariah Mengatasi Dampak Krisis Covid-19. Bogor: Institut Tazkia.

Iskandar, A., Aqbar, K. (2019). Kedudukan Ilmu Ekonomi Islam di Antara Ilmu Ekonomi dan Fikih Muamalah: Analisis Problematika Epistemologis. Nukhbatul 'Ulum: Jurnal Bidang Kajian Islam, Vol. 5, No. 2 (2019), h. 88-105.

Kasdi, A. (2016). Filantropi Islam Untuk Pemberdayaan Ekonomi Umat (Model Pemberdayaan ZISWAF di BMT Se-Kabupaten Demak). Iqtishadia: Jurnal Kajian Ekonomi dan Bisnis Islam STAIN Kudus, 9(2), 227-245.

Linge, A. (2015). Filantropi Islam Sebagai Instrumen Keadilan Ekonomi. Jurnal Perspektif Ekonomi Darussalam, 1(2), 154-171.

Lubis, N. I. (2019). Peran Masyarakat Ekonomi Syariah (MES) Dalam Meningkatkan Literasi Keuangan Syariah Di Indonesia (Doctoral dissertation, Universitas Islam Negeri Sumatera Utara).

Mubarok, F. K. (2019). Optimalisasi Produk Qardhul Hasan Dalam Memberdayakan Ekonomi Umat. AKUNTABEL, 16(1), 62-68. 
Sabirin, S., \& Sukimin, D. A. (2017). Islamic Micro Finance Melati: Sebuah Upaya Penguatan Permodalan bagi Pedagang Pasar Tradisional. Economica: Jurnal Ekonomi Islam, 8(1), 27-53.

Sakni, A. S. (2013). Konsep Ekonomi Islam dalam Mengentaskan Kesenjangan Sosial: Studi atas Wacana Filantropi Islam dalam Syari'at Wakaf. Jurnal Ilmu Agama: Mengkaji Doktrin, Pemikiran, dan Fenomena Agama, 14(1), 151-166).

Sakni, A. S. (2013). Konsep Ekonomi Islam dalam Mengentaskan Kesenjangan Sosial: Studi atas Wacana Filantropi Islam dalam Syari'at Wakaf. Jurnal Ilmu Agama: Mengkaji Doktrin, Pemikiran, dan Fenomena Agama, 14(1), 151-166.

Sari, S. P. (2015). Pengaruh Pembiayaan Qardhul Hasan Terhadap Peningkatan Pendapatan Usaha Mustahik Zakat (Studi Kasus Dompet Peduli Umat Daarut Tauhiid Cabang Bogor). AL-INFAQ, 4(1), 57-93.

Satrio, M. A. (2015). Qardhul Hasan Sebagai Wujud Pelaksanaan CSR dan Kegiatan Filantropi Lembaga Keuangan Syariah Untuk Pemberdayaan Masyarakat. Kajian Bisnis Sekolah Tinggi Ilmu Ekonomi Widya Wiwaha, 23(2), 104-111.

Surico, P., Galeotti, A. (2020). The economics of a pandemic: the Case of Covid-19. Working Paper. London Business School. p. 69-73.

Uyun, Q. (2015). Zakat, Infaq, Shadaqah, dan Wakaf Sebagai Konfigurasi Filantropi Islam. Islamuna: Jurnal Studi Islam, 2(2), 218-234.

World Bank. (2020). World Bank Group and COVID-19 (coronavirus). https://www.worldbank.org/en/who-we-are/news/coronavirus-covid19. Diakses pada tanggal 4 Mei 2020.

Yuliana, R. R. R. D. (2019). Sinergi Lembaga Teknologi Finansial dan Koperasi Dalam Pemanfaatan Teknologi Finansial Oleh Usaha Mikro, Kecil, dan Menengah di NTB. Jurnal Ekonomi dan Pembangunan, 27(1), 53-66. 
Azwar Iskandar, Bayu Taufiq Possumah, Khaerul Aqbar 


\section{Indexed by :}
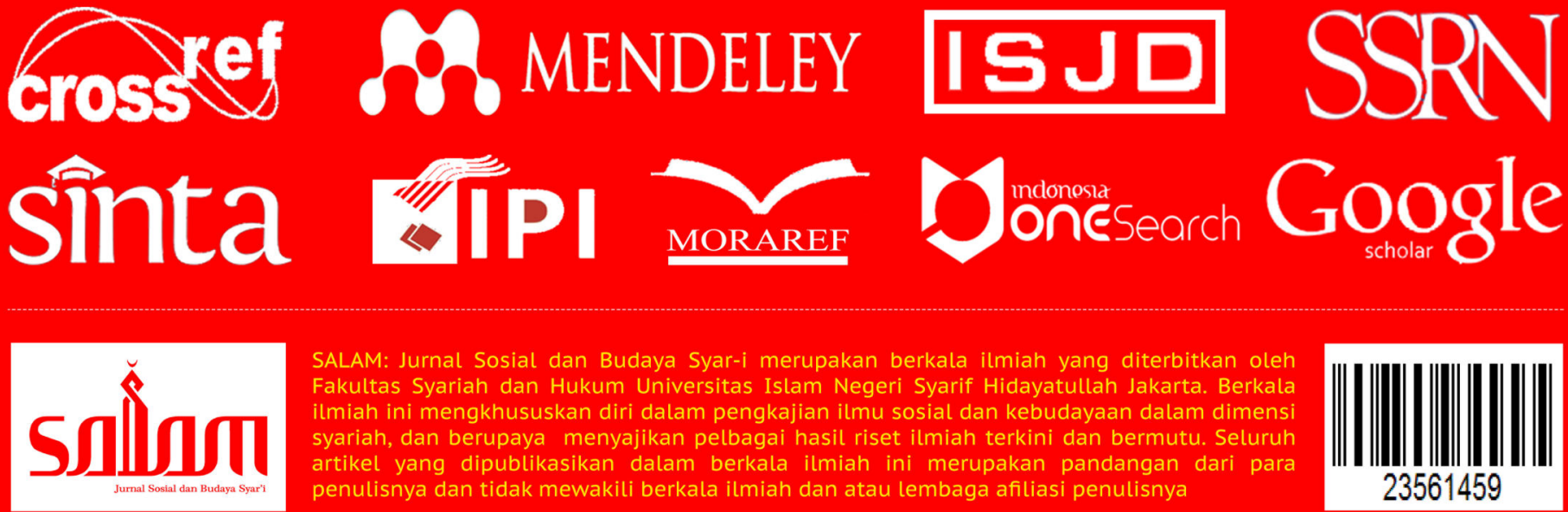

SALAM: Jurnal Sosial dan Budaya Syar-i merupakan berkala ilmiah yang diterbitkan oleh Fakultas Syariah dan Hukum Universitas Islam Negeri Syarif Hidayatullah Jakarta. Berkala ilmiah ini mengkhususkan diri dalam pengkajian ilmu sosial dan kebudayaan dalam dimensi syariah, dan berupaya menyajikan pelbagai hasil riset ilmiah terkini dan bermutu. Seluruh artikel yang dipublikasikan dalam berkala ilmiah ini merupakan pandangan dari para penulisnya dan tidak mewakili berkala ilmiah dan atau lembaga afiliasi penulisnya

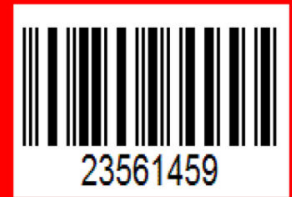

